\title{
Bibliografia literacka w Instytucie Badań Literackich Polskiej Akademii Nauk (1948-2010) - geneza, dokonania, perspektywy ${ }^{1}$
}

STreszczenie. Artykuł omawia bibliografie literackie opracowywane w Instytucie Badań Literackich PAN, ich genezę, specyfikę i założenia leżące u podstaw opracowań różnych typów bibliografii. Szczególną uwagę poświęcono bibliografiom literackim, które są dziełami zespołowymi, mającymi szeroki zakres i zasięg - takim jak: Bibliografia literatury polskiej "Nowy Korbut" oraz należące do tej serii słowniki: Słownik pisarzy polskich (Seria I i II) i Wspótcześni polscy pisarze i badacze literatury; Dawni pisarze polscy. Od początków piśmiennictwa do Młodej Polski. Przewodnik biograficzny i bibliograficzny; Słownik pseudonimów pisarzy polskich (XV w.-1995); Literatura polska i teatr w latach II wojny światowej. Bibliografia; Polska Bibliografia Literacka; Literatura i krytyka literacka poza cenzura 1977-1989; Kto był kim w drugim obiegu? Słownik pseudonimów pisarzy i dziennikarzy. 1976-1989; Bez cenzury 1976-1989. Literatura, ruch wydawniczy, teatr. Bibliografia; Bibliografia Bara. Kartoteka Bibliografii Literackiej Zawartości Czasopism Polskich XIX i XX wieku (do roku 1939). Bibliografie te mają na celu ukazanie faktów życia literacko-kulturalnego od początków piśmiennictwa do czasów współczesnych. Zaprezentowano dwie elektroniczne wersje bibliografii literackiej: PBL online - jako kontynuację książkowej bibliografii drukowanej Polska Bibliografia Literacka - oraz Bibliografię Bara - elektroniczną wersję kartoteki bibliograficznej Bibliografia Bara. Kartoteka Bibliografii Literackiej Zawartości Czasopism Polskich XIX i XX wieku (do roku 1939), opracowanej pod kierownictwem Adama Bara, zapoczątkowanej w latach II wojny światowej i ukończonej w latach 50. XX wieku. Poruszono także zagadnienie cenzury bibliografii literackich w latach 1948-1989, obecnej sytuacji opracowywania bibliografii literackich oraz zarysowano problem dokumentacji obszarów nieobjętych rejestracją bibliograficzną.

Wszystkie omówione bibliografie są bibliografiami retrospektywnymi, wskutek czego pojawiła się konieczność stworzenia dalekosiężnego planu dla opracowania PBL

\footnotetext{
${ }^{1}$ Autorka dziękuje Pani Profesor Jadwidze Czachowskiej za wskazanie tematu i konsultację merytoryczną.
} 
- bibliografii bieżącej, będącej podstawowym kompendium informacyjnym z dziedziny literatury i literaturoznawstwa, warsztatem dla badań literackich i źródłem wielu innych opracowań bibliograficznych, a także podstawą prac interpretacyjnych.

SŁowA KLuczowe: bibliografia, bibliografia literacka, Polska Bibliografia Literacka, literatura, historia literatury, motywy literackie, film, telewizja, teatr, informacja naukowa, dokumentacja naukowa, Instytut Badań Literackich, cenzura.

\section{Wstęp}

Specyfika badań naukowych z dziedziny literatury polega na zapoznaniu się z wynikami wcześniejszych badań oraz przyswojeniu tekstów literackich w danym zakresie ${ }^{2}$. Aby zapewnić informację naukową o tekstach literackich, ich opracowaniach krytycznych i naukowych, a także o materiale rzeczowym, zawartym w książkach i czasopismach, opracowuje się naukowe bibliografie literackie o różnych zasięgach i zakresach, których autorami są bibliografowie $\mathrm{z}$ wykształceniem filologicznym ${ }^{3}$. W Instytucie Badań Literackich Polskiej Akademii Nauk (IBL PAN) opracowano wiele takich bibliografii, dostępnych w postaci książek i kartotek. Są to bibliografie tekstów literackich, bibliografie opracowań krytycznych i naukowych, a także bibliografie rejestrujące teksty, prace krytyczne oraz literaturoznawcze. Informacja zawarta w bibliografiach odsyła użytkownika do źródeł - najczęściej książek lub czasopism, znajdujących się w bibliotekach.

Wielka dynamika zmian zarówno w otoczeniu samej nauki, jak i w sferze technologii informacyjnych, informatycznych i telekomunikacyjnych (m.in. cyfryzacja dokumentów oraz szerokie wykorzystanie Internetu) jest widoczna w bibliotekach (np. komputerowe katalogi biblioteczne, biblioteki cyfrowe) oraz w samej bibliografii, w której nastąpiła zmiana nośnika informacji bibliograficznej z formy drukowanej na elektroniczną. Liczne bibliografie różnych dziedzin nauki są teraz ogólnodostępnymi, komputerowymi bazami danych. Niektóre bibliografie dziedzinowe nie odsyłają już użytkownika do książki lub czasopisma w formie druków, przechowywanych w zbiorach bibliotecznych, lecz pod opisem bibliograficznym

\footnotetext{
2 J. Czachowska, Rozwój bibliografii literackiej w Polsce, Wrocław 1979, s. 62.

${ }^{3} \mathrm{~W}$ odniesieniu do spisów bibliograficznych o trzech różnych zakresach termin „bibliografia literacka” obejmuje: 1. Literaturę polska; 2. Historię literatury polskiej i krytykę literacka, literaturę polską oraz prace historyczno- i teoretycznoliterackie, krytykę literacką; 3. Literaturę polską oraz prace historyczno- i teoretycznoliterackie, krytykę literacka, a nadto materiały dotyczące życia literackiego. Zob. J. Czachowska, Rozwój bibliografii..., s. 7.
} 
widnieje łącze (link) do cyfrowej postaci dokumentu, umieszczonej na innym serwerze. Zwiększające się zasoby bibliotek cyfrowych umożliwiają rozległy dostęp do wielu druków zwartych.

Bibliografie literackie, chociaż w mniejszym stopniu, również uległy tym zmianom, zachowując jednak wiele cech łączących je z wielkimi dokonaniami bibliografii opracowanych w formie drukowanej. Rozwój bibliografii innych dziedzin zmusza do przewartościowania dotychczasowych koncepcji, sądów i opinii dotyczących bibliografii literackich. Osiągnięcia dokumentalistyki literackiej są mało znane, głównie z powodu ograniczonego dostępu do nich (były wydawane jako pozycje niskonakładowe, na ogół niewznawiane, wiele bibliografii istnieje tylko $\mathrm{w}$ postaci kartotek), a krąg odbiorców ograniczał się do środowiska badaczy naukowych. W celu umożliwienia powszechnego dostępu do unikatowych bibliografii drukowanych digitalizuje się je i udostępnia w bibliotekach cyfrowych ${ }^{4}$.

\section{Geneza współczesnych bibliografii literackich}

Potrzeba prowadzenia systematycznych prac bibliograficznych zarówno o charakterze ogólnym, jak i w zakresie poszczególnych dziedzin wiedzy pojawiła się na terenie Polski w połowie XIX wieku. Prace bibliograficzne, podejmowane jednostkowo, odbywały się w bardzo trudnych warunkach politycznie rozbitego państwa, cenzury zaborcy oraz braku środków materialnych na edycję. Celem takich prac bibliograficznych było naukowe udokumentowanie dorobku piśmienniczego, a także chęć uświadomienia bogactwa polskiej kultury narodowej i jej odrębności oraz ukazanie kompletnego i całościowego zasobu polskiego piśmiennictwa. Szczególnym obszarem penetracji bibliograficznej stała się literatura piękna: druki zwarte, zawierające teksty literackie rozproszone po bibliotekach dworskich, klasztornych i kolekcjach prywatnych. Ówczesny bibliograf to człowiek z pasją badawcza, dociekliwy miłośnik świata książek i pisarzy, najczęściej o gruntownym wykształceniu historycznoliterackim i filologicznym ${ }^{5}$. W tym okresie powstała Bibliografia polska Karola Estreichera (wydawana w latach 1869-1908).

Na potrzeby historii literatury zaczęto opracowywać bibliografie literackie, a jej najwcześniejszą próbą była Bibliografia z zakresu historii literatury i oświaty w Polsce (za lata 1877-1881), przygotowana przez Władysława

\footnotetext{
${ }^{4}$ Planuje się w niedalekiej przyszłości digitalizację drukowanych roczników Polskiej Bibliografii Literackiej i udostępnianie w Wielkopolskiej Bibliotece Cyfrowej.

${ }^{5}$ S. Vrtel-Wierczyński, Teoria bibliografii w zarysie, Wrocław 1951, s. 47 i n.
} 
Wisłockiego i wydana we Lwowie w latach 1878 i 1882. We wstępie do Polskiej Bibliografii Literackiej za lata 1944/1945 o tej inicjatywie tak pisze Stefan Vrtel-Wierczyński:

Jądrem zagadnienia było opanowanie zawartości czasopism polskich i połączenie jej z materiałem książkowym (dziełami literackimi i naukowymi) w jedną systematyczną i metodologiczną całość. Zorientowanie się w drukach zwartych (książkach i broszurach) było ułatwione dzięki dobrej pomocy „Przewodnika Bibliograficznego", który utrzymywał je w regularnej biograficznej ewidencji. Znacznie trudniejsza była sprawa z czasopismami i dziennikami: tkwiła w nich olbrzymia masa materiału literackiego i naukowego, ukrytego $\mathrm{w}$ trudno dostępnych blokach potężnych roczników współczesnych i dawniejszych. Na łamach prasy periodycznej i codziennej debiutowali swymi pierwszymi utworami poeci i pisarze głośni później i wielcy w literaturze; pojawiały się tam utwory dawniejsze nie wydane, korespondencje literackie, prace i artykuły historycznoliterackie i krytyczne, recenzje, polemiki, sprawozdania, przeglądy; było też mnóstwo innego materiału z dziedzin pogranicznych i pokrewnych, nieobojętnych dla badacza zjawisk literackich, ich dziejów, rozwoju i znaczenia ${ }^{6}$.

Kolejną inicjatywą było wydawanie „Pamiętnika Literackiego” (od 1902 roku) przez Towarzystwo Literackie im. Adama Mickiewicza we Lwowie. Zamieszczano w nim Bibliografie literacka czasopism polskich $\mathrm{w}$ formie zestawień bibliograficznych. Jedno z takich zestawień - Bibliografię historii literatury i krytyki literackiej polskiej za rok 1905 (wyd. 1907) - opracował Vrtel-Wierczyński. Została też opublikowana pierwsza synteza historycznoliteracka Młodej Polski Wilhelma Feldmana - dwutomowe Piśmiennictwo polskie. 1880-1904 (Lwów 1902), uzupełniona trzecim tomem zatytułowanym Wspótczesna literatura polska.

W okresie międzywojennym wydana została w trzech tomach (w latach 1917-1921) Literatura polska od początków do powstania styczniowego. Książa podręczna informacyjna dla studiujacych naukowo dzieje rozwoju piśmiennictwa polskiego Gabriela Korbuta, kierownika Gabinetu Filologicznego Towarzystwa Naukowego Warszawskiego, będąca pierwszą polską retrospektywną bibliografią literacką łączącą biogramy autorów z wykazem ich utworów oraz opracowań (bibliografią podmiotową i przedmiotową). Wśród innych dokonań w tej dziedzinie na uwagę zasługują także prace bibliograficzne Kazimierza Czachowskiego.

\footnotetext{
${ }^{6}$ S. Vrtel-Wierczyński, Słowo wstępne, w: Polska Bibliografia Literacka za lata 1944-1945, Wrocław 1957, s. VII-XII.
} 
Lata 1918-1939 to także okres, w którym Vrtel-Wierczyński przystąpił do organizowania prac zespołowych nad bieżącą bibliografią literacką gdyż uważał, że bibliografia literacka o szerokim zakresie i zasięgu źródłowym może być zorganizowana tylko jako praca zespołowa. Przygotował szczegółowe instrukcje do przygotowania takiej bibliografii. W jego opracowaniu, nakładem Towarzystwa Literackiego we Lwowie, ukazały się dwa roczniki takiej bibliografii: Bibliografia literatury polskiej za rok 1919 (wyd. 1926) i Bibliografia literatury polskiej za rok 1922 (wyd. 1925). Szczególną uwagę $w$ tych bibliografiach przywiązywano do rejestracji utworów literackich i artykułów dotyczących literatury, rozproszonych w czasopismach naukowych, literackich, politycznych, a także w wydawnictwach zbiorowych. Ze względu na zmieniające się warunki społeczno--polityczne tego okresu i dążenia do przedstawienia kompletnego obrazu bibliograficznego obszar penetracji źródeł bibliograficznych znacznie się poszerzył i zaczął obejmować również czasopisma i druki zwarte niemające ścisłego związku z literaturą, a z różnych względów zawierające tego typu materiały. Bibliograficzne osiągnięcia Vrtela-Wierczyńskiego stały się podstawą współczesnych bibliografii literackich: Polskiej Bibliografii Literackiej, Bibliografii literatury polskiej "Nowy Korbut” oraz słowników biobibliograficznych.

\section{Bibliografia literacka w Instytucie Badań Literackich ${ }^{7}$}

W 1948 roku powstał Instytut Badań Literackich, którego zadaniami statutowymi były prowadzenie historyczno- i teoretycznoliterackich badań naukowych oraz systematyczne opracowywanie oraz wydawanie prac bibliograficznych i edytorskich. Do realizacji szeroko zakrojonych prac bibliograficznych na potrzeby badań literackich i edytorskich - głównie bibliografii obejmujących literaturę polska, prace historyczno- i teoretycznoliterackie, krytykę literacką oraz materiały dotyczące życia literackiegostworzono wyspecjalizowane zespoły dokumentalistów. Ich zadaniem było między innymi kontynuowanie w zaktualizowanej i unowocześnionej formie przedwojennych przedsięwzięć - Bibliografii literatury polskiej "Nowy Korbut”, realizowanie projektu literackiej bibliografii bieżącej Vrtela-Wierczyńskiego - Polskiej Bibliografii Literackiej, a także tworzenie

${ }^{7}$ Wykaz prac powstałych w IBL PAN w latach 1948-2001, w tym bibliografii, rejestruje praca: Instytut Badań Literackich Polskiej Akademii Nauk 1948-2001. Ksiażki i czasopisma - bibliografia, oprac. K. Batora, B. Tyszkiewicz, red. J. Czachowska, Warszawa 2002. 
nowych typów bibliografii literackich (m.in. słownik pseudonimów pisarzy polskich, monografie biobibliograficzne pisarzy, kalendaria życia i twórczości pisarzy, bibliografie zawartości poszczególnych czasopism literackich, bibliografie gatunków i motywów literackich, przewodniki dla użytkowników bibliografii literackich). Celem tych wszystkich zamierzeń było stworzenie odpowiedniej bazy faktograficznej - podstawy rzetelnych badań historycznoliterackich i interpretacyjnych.

Prace bibliograficzne prowadzono w pracowniach Instytutu Badań Literackich w Warszawie, Krakowie, Wrocławiu i Poznaniu. Powstawały także indywidualne prace $\mathrm{w}$ zakresie bibliografii literackiej. Wytyczano obszary dokumentacji bibliograficznej, doskonalono metody opisu bibliograficznego, zmieniano struktury bibliografii, a także przystosowywano bibliografię do rejestrowania innego typu publikacji niż teksty drukowane (płyty, filmy, audycje radiowe, spektakle teatralne). W ostatnim dziesięcioleciu udostępniono użytkownikom bibliografię na nowym typie nośnika informacji, jakim są pamięci komputerowe: Polska Bibliografia Literacka w postaci komputerowej bazy danych oraz Bibliografia Bara. Kartoteka Bibliografii Literackiej Zawartości Czasopism Polskich XIX i XX wieku (do roku 1939).

\section{Bibliografie literackie obejmujące utwory literackie i naukę o literaturze}

\section{Bibliografia literatury polskiej „Nowy Korbut"}

Jednym z największym przedsięwzięć bibliograficznych było opracowanie Bibliografii literatury polskiej "Nowy Korbut”, rozpoczęte pod redakcją Kazimierza Budzyka w 1950 roku. Bibliografia "Nowy Korbut”, która miała być uzupełnieniem dzieła biobibliograficznego Gabriela Korbuta Literatura polska. Ksiażka podręczna informacyjna dla studiujących naukowo dzieje rozwoju piśmiennictwa polskiego, stała się fundamentalną bibliografią literatury polskiej, gruntownie zmieniona, poprawioną i uzupełnioną $\mathrm{w}$ stosunku do pierwowzoru, zaś niektóre hasła osobowe stały się monografiami bibliograficznymi pisarzy ${ }^{8}$. Ze względu na wielką wagę tego dzieła, sposób opracowania (często były to własne badania źródłowe członków zespołu bibliografów) i zakres zebranych materiałów, odpowiadający na zapotrzebowanie naukowe, należy przypomnieć, że tomy 1-3 - Piśmiennic-

\footnotetext{
${ }^{8} \mathrm{Na}$ temat opracowywania Bibliografii literatury polskiej „Nowy Korbut” zob. J. Czachowska, Rozwój bibliografii..., s. 164-186.
} 
two staropolskie - opracował zespół pod kierunkiem Romana Pollaka i Tadeusza Witczaka w Poznaniu (wyd. 1963-1965), tomy 4-6 - Oświecenie zespół pod kierunkiem Tadeusza Mikulskiego i Elżbiety Aleksandrowskiej we Wrocławiu (wyd. 1966-1972), tomy 7-9 - Romantyzm - zespół pod redakcją Irminy Śliwińskiej i Stanisława Stupkiewicza w Warszawie (wyd. 1968-1972), tomy 13-16 - Literatura pozytywizmu i Młodej Polski-zespół pod redakcją Jarosława Maciejewskiego i Zygmunta Szweykowskiego w Poznaniu (wyd. 1970-1978). Piątą częścią Bibliografii literatury polskiej "Nowy Korbut" jest Słownik współczesnych pisarzy polskich, t. 1-4, opracowany pod redakcją Ewy Korzeniewskiej w Instytucie Badań Literackich w Warszawie (wyd. 1963-1966). Słownik ten obejmował twórczość 826 pisarzy i badaczy literatury pierwszej połowy XX wieku (1918-1950), debiutujących przed rokiem 1950, a granica podawanych informacji był rok 1957. Zawierał również hasła rzeczowe instytucji i grup literackich. Suplementem i kontynuacją tego kompendium biobibliograficznego jest Słownik wspótczesnych pisarzy polskich. Seria II, t. 1-3, opracowany pod redakcją Jadwigi Czachowskiej (wyd. 1967-1980). Obejmuje hasła 473 pisarzy debiutujących w latach 1950-1965.

Wybitnym polskim pisarzom poświęcono tomy monograficzne „Nowego Korbuta" - t. 11: Juliusz Słowacki (w opracowaniu Haliny Gacowej, wyd. 2000), t. 12: Józef Ignacy Kraszewski (w opracowaniu Stanisława Stupkiewicza, Irminy Śliwińskiej i Wandy Roszkowskiej-Sykałowej, wyd. 1966), t. 17, vol. 1: Bolesław Prus (w opracowaniu Teresy Tyszkiewicz, wyd. 1981), t. 17, vol. 2: Eliza Orzeszkowa (w opracowaniu Haliny Gacowej, wyd. 1999), t. 18: Jan Kasprowicz (w opracowaniu Romana Lotha, wyd. 1994). Obecnie kontynuowane są prace nad dalszymi tomami monograficznymi „Nowego Korbuta", poświęconymi Henrykowi Sienkiewiczowi, Stanisławowi Wyspiańskiemu (tom przygotowany do druku w opracowaniu Wiesławy Albrecht-Szymanowskiej) oraz Adamowi Mickiewiczowi.

Rozciągnięta w czasie realizacja bibliografii „Nowy Korbut” (od 1963) wymagała systematycznych uzupełnień i aktualizacji. W 1976 roku podjęto takie prace, a jednocześnie zainicjowano opracowanie nowego słownika biobibliograficznego o szerszym przeznaczeniu czytelniczym, z zastosowaniem większej selekcji materiału bibliograficznego. Słownik ten miał oferować możliwie najnowszy stan wiedzy biograficznej i bibliograficznej z dziedziny historii literatury polskiej: miał być podręcznym, powszechnie dostępnym i funkcjonalnym kompendium informacyjnym ${ }^{9}$. W wyniku tych prac powstał w 1987 roku słownik „Pisarze polscy. Przewodnik

\footnotetext{
${ }^{9}$ R. Loth, Uwagi wstępne, w: Dawni pisarze polscy. Od poczatków piśmiennictwa do Młodej Polski. Przewodnik biograficzny i bibliograficzny, t. 1: A-H, Warszawa 2000, s. 5-8.
} 
biobibliograficzny", mający być zaktualizowaną miniaturyzacją "Nowego Korbuta", obejmującą hasła pisarzy tworzących w okresach od staropolszczyzny po współczesność. Wskutek niesprzyjających warunków nie został jednak wydany drukiem i zachował się jedynie w maszynopisie.

Na podstawie tego słownika został opracowany przewodnik biograficzny i bibliograficzny Dawni pisarze polscy. Od poczq̨tków piśmiennictwa do Młodej Polski pod redakcją Romana Lotha (t. 1-4, wyd. 2000-2004), obszerne kompendium informacyjne w zakresie dziejów literatury polskiej od jej początków po rok 1918. Zakres chronologiczny, dobór haseł, kryteria selekcji materiałów bibliograficznych, układ hasła, typ narracji bibliograficznej, szczegóły opisu - ustalił pierwotny zespół autorski nieopublikowanego słownika "Pisarze polscy” pod redakcja Jarosława Maciejewskiego. Dawni pisarze polscy to słownik pisarzy polskich, ale nie wyłącznie polskojęzycznych. Obejmuje również przebywających w Polsce autorów polsko-łacińskich i piszących po łacinie, a także tworzących w języku francuskim i niemieckim, związanych z kulturą polską. Ze względów formalnych przeprowadzono selekcję haseł, uwzględniając tylko tych pisarzy, którzy - zdaniem zespołu redaktorów - swoją twórczością zapisali się w dziejach literatury polskiej. Selekcji podległ także materiał bibliograficzny: $\mathrm{w}$ bibliografii podmiotowej pominięto między innymi drobne i zaginione utwory pisarzy, natomiast w bibliografii przedmiotowej ograniczono się do opracowań najważniejszych.

Dział współczesny leksykonu „Pisarze polscy” został opracowany w formie słownika Wspótcześni polscy pisarze i badacze literatury pod redakcją Jadwigi Czachowskiej i Alicji Szałagan (t. 1-10, wyd. 1994-2007). Słownik ten jest kontynuacją Słownika pisarzy polskich - Serii I i II. Zawiera około 2000 haseł współczesnych pisarzy polskich, reportażystów, tłumaczy, historyków i teoretyków literatury. W dziesięciu tomach słownika umieszczono biogramy, bibliografię podmiotową i przedmiotową pisarzy i badaczy literatury debiutujących po 1918, do 1988 roku. Zawarto w nim życiorysy pisarzy nieskażone ingerencjami cenzury oraz zarejestrowano ich publikacje z obszaru niezależnego ruchu wydawniczego. Słownik obejmuje grupę autorów, których haseł nie zawiera Słownik pisarzy polskich, oraz autorów, którzy przed rokiem 1988 wydali trzy książki. Jest to największy tego typu leksykon w Polsce i stanowi dokumentację twórczości pisarzy polskich mieszkających w Polsce i za granicą. Podstawą źródłową do opracowania tego leksykonu są opisy bibliograficzne zebrane przez zespół autorski Polskiej Bibliografii Literackiej Pracowni Bibliografii Bieżącej Instytutu Badań Literackich w Poznaniu. 


\section{Słownik pseudonimów pisarzy polskich (XV w.-1995)}

Słowniki biobibliograficzne to kompendia informacyjne, zawierające dane biograficzne i bibliograficzne dotyczące twórczości oraz opracowań krytycznych i naukowych poszczególnych pisarzy. Szczególnym typem słownika bibliograficznego jest Słownik pseudonimów pisarzy polskich. XV w.-1995 (SPPP), opracowany zespołowo pod redakcją Edmunda Jankowskiego $^{10}$.

Pisarze sygnowali swoje teksty pseudonimami w różnych epokach, a szczególne nasilenie tego zjawiska wystąpiło w XIX i XX wieku. Odnotowywały to słowniki pseudonimów, opracowywane według różnych metod w poszczególnych epokach. Nigdy dotąd nie stworzono jednak słownika pseudonimów pisarzy ze wszystkich epok literackich. SPPP rozwiązuje 55000 pseudonimów ze wskazaniem ich miejsca występowania oraz zestawienie nazwisk około 16000 autorów sygnujących swoje teksty pseudonimami, głównie w czasopismach.

Przyjęta na potrzeby Słownika definicja pseudonimu literackiego określa, że jest nim każde celowe oznaczenie autorstwa jakiejkolwiek pracy literackiej czy paraliterackiej (drukowanej lub rękopiśmiennej) w sposób różniący się od aletonimu, czyli od imienia i nazwiska obowiązującego w cywilnym życiu autora, co oznacza, że kryptonim jest także pseudonimem. Było to jedyne rozwiązanie, gdyż pisarze znani pod pseudonimami, jak np. Jan Brzechwa, Bolesław Prus czy Gabriela Zapolska, oprócz jednego znanego pseudonimu używali także innych, a ich prawne nazwiska były nieużywane. Inni pisarze, jak np. Zygmunt Krasiński, Julian Tuwim, Maria Konopnicka, publikowali pod kilkoma pseudonimami, bez których rozwiązania nie można by poznać ich twórczości. Są nazwiska pisarzy, u których liczba używanych pseudonimów przekraczała 70. Obliczono, że w Stowniku średnio na jednego pisarza przypadają trzy pseudonimy.

Zakres czasowy tej bibliografii jest ogromny - obejmuje autorów polskich działających w kraju i za granicą od początków literatury polskiej po rok 1995. W stosunku do autorów żyjących starano się, na podstawie specjalnej ankiety, uzyskać od nich potwierdzenie prawdziwości rozwiązania pseudonimów już wymienionych w kompendiach literackich, bibliografiach, prasie, a także otrzymać zgodę na ujawnienie w Słowniku nowych pseudonimów, dotąd oficjalnie nierozszyfrowanych. Starano się wyczer-

${ }^{10}$ Stownik pseudonimów pisarzy polskich. XV w.-1995, t. 1-5, red. E. Jankowski, D. Świerczyńska, Warszawa 1994-1998; zob. też: E. Jankowski, Słownik pseudonimów, czyli "larva detracta", w: Dokumentacja w badaniach literackich i teatralnych. Wybrane problemy, red. J. Czachowska, Wrocław 1970, s. 149-181. 
pująco rozwiązać pseudonimy autorów druków zwartych. Pseudonimy $\mathrm{z}$ publikacji $\mathrm{w}$ wydawnictwach ciągłych wybrano $\mathrm{z}$ istniejących już różnych opracowań drukowanych oraz pozostających w kartotekach. Takimi źródłami były m.in. Bibliografia polska Estreichera, tomy Bibliografii literatury polskiej „Nowy Korbut”, Kartoteka Bibliografii Literackiej Zawartości Czasopism Polskich XIX i XX wieku (do roku 1939), Polski Słownik Biograficzny, Polska Bibliografia Literacka, Słownik pseudonimów i kryptonimów pisarzy polskich oraz Polski dotyczacych Adama Bara, a także kartoteki badaczy i zbieraczy hobbystów. Nie zamieszczono wykazu pseudonimów nierozwiązanych. SPPP składa się z części wstępnej, części pierwszej zawierającej wykaz pseudonimów i ich rozwiązań oraz części drugiej będącej wykazem nazwisk nosicieli pseudonimów. Ze względu na specyfikę układu tego Słownika należy podać główne składniki hasła pseudonimowego: w pozycji hasłowej występuje pseudonim, następnie podany jest aletonim (nazwisko autora prawnie obowiązujące), miejsca występowania pseudonimu (charakter publikacji i data roczna) oraz źródło rozwiązania pseudonimu. W części drugiej hasło autorskie składa się z nazwiska cywilnego autora (aletonim), daty oraz miejsca urodzenia i śmierci, biogramu oraz pseudonimów używanych przez autora (rozwiązanych w części pierwszej).

\section{Literatura polska i teatr w latach II wojny światowej}

Innym rodzajem bibliografii opracowywanych przez zespoły bibliografów są kompendia, których nadrzędną funkcją jest ukazanie obrazu literatury polskiej w wyodrębnionym okresie, wzbogaconego o materiał krytyczny i naukowy, dotyczący nie tylko poszczególnych pisarzy i badaczy literatury, ale także dorobku naukowego w zakresie historii i teorii literatury, życia literackiego i teatralnego, czy też recepcji literatur obcych w Polsce.

Unikatowa bibliografia Jadwigi Czachowskiej, Marii Krystyny Maciejewskiej i Teresy Tyszkiewicz Literatura polska $i$ teatr w latach II wojny światowej (t. 1-3, wyd. 1983-1986) dokumentuje życie literackie i kulturalne okresu 1939-1945, nie ogranicza się jedynie do terytorium Polski, lecz ogarnia wszystkie skupiska Polaków na całym świecie, uwzględniając także twórczość Polaków publikujących w językach obcych. Bibliografia ta zawiera nowatorskie rozwiązania i założenia bibliograficzne, jest wzorem dla innych bibliografii rejestrujących nietypowe materiały, powstające w konspiracji, w sytuacji zagrożenia państwa i niepodległości, czy też w środowiskach Polaków mieszkających poza krajem; ukazuje jedność kultury polskiej w kraju i na emigracji. 
We Wstępie ${ }^{11}$ autorki pisza, że głównymi zadaniami tej bibliografii było stworzenie podstawy dokumentacyjnej do opracowań interpretacyjnych życia literackiego w latach 1939-1945 oraz wypełnienie luki w dokumentacji dotyczącej wybitnych pisarzy polskich, którzy w tym okresie prowadzili ożywioną działalność literacką. Zarejestrowane materiały to: utwory literackie i paraliterackie (reportaże, korespondencje, dzienniki, wspomnienia, felietony) w języku polskim lub autorstwa Polaków bez względu na język publikacji, przekłady z literatur obcych na język polski, prace historycznoliterackie i krytyczne oraz prace autorów obcych o literaturze polskiej, materiały dotyczące polskiego życia literackiego, kulturalnego i naukowego oraz materiały dotyczące polskiego teatru. Zasięg terytorialny rejestrowanych druków zwartych (książek i broszur), ulotek, utworów niesamoistnych wydawniczo (lub ich fragmentów, np. motta i cytaty z dzieł wybitnych pisarzy, publikowanych w książkach zbiorowych oraz czasopismach i dziennikach) to okupowana przez Niemców Polska, gdzie życie kulturalne rozwijało się w podziemiu, oraz skupiska Polaków w różnych krajach Europy i poza nia, gdzie na szlaku żołnierskim i uchodźczym rozwijało się polskie życie kulturalne i literackie (Rumunia, Węgry, Francja, Szwajcaria, Anglia, Związek Radziecki, Bliski Wschód, Włochy, Stany Zjednoczone).

Poszukiwaniami materiałów do bibliografii objęto biblioteki i archiwa w Polsce oraz w Londynie, Glasgow, Paryżu, Watykanie, Rzymie, Nowym Jorku i w Stanford. Kwerendą objęto także zbiory prywatne w Polsce i za granicą. Opracowana zawartość z ponad 800 wybranych czasopism oraz druków zwartych to ponad 30000 opisów bibliograficznych, które zgrupowano w działach: I. Literatura polska (1. Antologie, książki zbiorowe, śpiewniki; 2. Hasła osobowe; 3. Utwory anonimowe i ulotne; 4 . Hasła rzeczowe). II. Teatr polski (1. Teoria i historia teatru; 2. Teatr współczesny; 3. Ludzie teatru; 4. Teatry we wrześniu i październiku 1939 roku; 5. Teatry polskie na ziemiach polskich pod okupacją niemiecka; 6 . Teatry na terenach dawnych województw wschodnich RP; 7. Teatry w Polsce Ludowej (do 8 V 1945); 8. Teatry na emigracji; 9. Teatry żołnierskie; 10. Teatry w obozach jenieckich i uchodźczych). III. Literatury i teatry obce w recepcji polskiej (podział wg literatur narodowych); Aneks: Literatura i teatr w wydawnictwach niemieckich $w$ języku polskim (obejmuje druki zwarte i utwory z dziewięciu czasopism wydawanych przez okupanta w Warszawie, Krakowie i Lwowie).

${ }^{11}$ J. Czachowska, M.K. Maciejewska, T. Tyszkiewicz, Literatura polska i teatr w latach II wojny światowej. Bibliografia, t. 1, Wrocław 1983, s. V-IX. 


\section{Polska Bibliografia Literacka}

Bibliografia, która ukazuje obraz literatury polskiej w jej wszystkich formach przekazu (literatura drukowana, teatr, film, radio, telewizja), wydawaną w postaci roczników jest Polska Bibliografia Literacka (ukazująca się w latach 1953-2000 w postaci drukowanych roczników za lata 1944/45-1988, roczniki za lata 1989-1997 dostępne są w Internecie w postaci bibliograficznej bazy danych). Bibliografia ta jest opracowywana w Pracowni Bibliografii Bieżącej Instytutu Badań Literackich w Poznaniu. Pracownia rozpoczęła swą działalność pod kierownictwem prof. Stefana Vrtela-Wierczyńskiego w 1948 roku, a jej głównym zadaniem było opracowanie i ogłaszanie drukiem adnotowanej Polskiej Bibliografii Literackiej (PBL), rejestrującej: 1. Polskie teksty literackie wydane w postaci druków zwartych (książek i broszur) oraz teksty literackie i paraliterackie ogłaszane w prasie periodycznej, codziennej i w wydawnictwach zbiorowych; 2. Prace naukowoliterackie wydane osobno lub opublikowane na łamach czasopism zbiorowych (studia, rozprawy, artykuły, notatki, recenzje, sprawozdania); 3. Materiał dotyczący literatur obcych w Polsce (przekłady, opracowania) ${ }^{12}$.

Miała to być - w założeniu Vrtela-Wierczyńskiego - bibliografia, która byłaby kompletnym obrazem literatury polskiej (autorstwo, geografia literacka, tematyka, źródła, popularyzacja, czytelnictwo) i która dawałaby dokumentację życia literackiego. W sprawozdaniu z działalności Pracowni z 1958 roku czytamy:

PBL panuje nad współczesną twórczością literacką, starając się - w miarę możności - teksty literackie zbierać, opisywać, systematyzować oraz udzielać o nich źródłowej informacji dokumentacyjnej. [...] Dzięki PBL wszelkie przyszłe prace historycznoliterackie: monograficzne i syntetyczne będą znacznie ułatwione, ponieważ istnieje kompletnie zebrany materiał literacki i naukowoliteracki, którym można swobodnie operować, zakładając fundamenty koncepcji, budując konstrukcje całościowe, wysnuwając wnioski i uogólnienia. Dla uzupełnienia dodać należy, że opisany wyżej obraz bibliograficzny, jaki daje PBL, dotyczy głównie i przede wszystkim literatury polskiej i nauki o literaturze w kraju i zagranicą (polonica zagraniczne), obok tego zaś recepcji literatur obcych na gruncie polskim (przekłady polskie i opracowania). [...] PBL jest dokumentacją polskiego życia literackiego i naukowoliterackiego, jego bibliograficznym obrazem $\mathrm{w}$ ujęciu rocznym oraz obrazem recepcji literatur obcych na gruncie

${ }^{12}$ S. Vrtel-Wierczyński, Słowo wstępne, w: Polska Bibliografia Literacka za rok 1948, Warszawa 1954, s. VII-VIII. 
polskim. Uwzględniając źródłowo czasopiśmiennictwo polskie i (w wyborze) zagraniczne, zbiera, rejestruje, opisuje i systematyzuje teksty literackie - górując tym nad różnymi innymi bibliografiami; w tej dziedzinie PBL wysuwa się na czoło w skali międzynarodowej ${ }^{13}$.

Od rocznika PBL za 1966 (wyd. 1969), z chwilą przejęcia redakcji naukowej przez Jadwigę Czachowska, zawartość bibliografii została poszerzona o rejestrację tekstów literackich nagranych na płytach gramofonowych, wzbogacono zasób informacji z zakresu teatru (pełen repertuar poszczególnych scen zawodowych i recenzje spektakli, teoria, historia i organizacja), filmu (zestawienie produkcji pełnometrażowych polskich filmów fabularnych i filmów telewizyjnych), radia i telewizji (repertuar teatru radiowego i telewizyjnego ogólnopolskich programów Polskiego Radia i Telewizji). Wiązało się to z opracowaniem i doskonaleniem metodologii tworzenia opisów bibliograficznych takich materiałów, aby nadal w sposób czytelny i jednoznaczny określały rejestrowany materiał bibliograficzny. Zaczęto także rejestrować wydania książkowe wspomnień i reportaży pisarzy emigracyjnych ${ }^{14}$.

We wstępie do PBL za rok 1967 (wyd. 1970) redaktorka tomu Krystyna Tokarzówna ${ }^{15}$ pisała o zmianie układu materiału bibliograficznego. Opisy bibliograficzne zgromadzone są w czterech działach: 1. Teoria literatury (w tym dziale prof. Janusz Sławiński dokonał zmiany układu haseł i częściowo ich nazw, przyjmując za podstawę używane w tej dziedzinie nauki o literaturze podział i terminologię); 2. Literatura polska (w części rzeczowej wyróżniono rozdziały: Historia literatury, Literatura współczesna, Zagadnienia specjalne, Organizacja nauki o literaturze); 3. Literatury obce; 4. Teatr, film, radio, telewizja.

Powyższa struktura działów PBL jest też obecna w wersji elektronicznej PBL, zmodyfikowana jedynie w dziale „Teoria literatury” przez prof. Ryszarda Nycza.

Podczas prac nad rocznikiem PBL za 1985 zauważono, że „Przewodnik Bibliograficzny” nie rejestruje już wszystkich wydań książkowych z dziedziny literatury, rozszerzono zatem własny zakres poszukiwań druków zwartych nierejestrowanych tą drogą. Odnotowano też zmiany instytu-

${ }^{13}$ Pracownia Bibliograficzna w Poznaniu, „Biuletyn Polonistyczny” 1958, z. 2, s. 17-28.

${ }^{14}$ J. Formanowicz, Polska Bibliografia Literacka, „Poradnik Bibliotekarza” 20, 1968, s. 14-15; T. Tyszkiewicz, Pracownia Bibliografii Bieżacej w Poznaniu, „Biuletyn Polonistyczny" 32, 1989, z. 3/4, s. 28-34.

${ }^{15}$ K. Tokarzówna, Wstęp, w: Polska Bibliografia Literacka za rok 1968, Warszawa 1971, s. VII-VIII. 
cjonalne $\mathrm{w}$ dziedzinie teatru - zamiast jedności gmachu i instytucji pojawia się teatr impresaryjny. Aktorzy i zespoły teatralne występują na różnych scenach i w różnych miejscach, niezwiązanych $\mathrm{z}$ teatrem, co również wpłynęło na modyfikację opisu bibliograficznego ${ }^{16}$. Ostatnim rocznikiem drukowanym PBL była bibliografia za rok 1988 (wyd. 2000).

Należy zaznaczyć w tym miejscu, że opóźnienia w rejestracji materiałów w PBL zaczęły się podczas opracowywania i publikacji rocznika za rok 1985, w którym nastąpił także znaczny przyrost druków zwartych i materiałów czasopiśmienniczych, co przy skromnym składzie osobowym powodowało także wydłużenie czasu opracowania każdego następnego rocznika. Ze względu na zwiększająca się objętość PBL i ogromne koszty druku tej publikacji rocznik za 1985 od etapu zbierania materiałów do momentu wydania był opracowywany przez zespół PBL. Dotyczyło to także kolejnych roczników. W sumie - roczniki PBL za lata 1985-1988 powstały prawie w całości w Pracowni Bibliografii Bieżącej IBL PAN w Poznaniu, a zespół autorski zajmował się również dystrybucją wydanych roczników.

W 1997 roku powstała elektroniczna wersja wielodziedzinowej, adnotowanej Polskiej Bibliografii Literackiej, a materiał za rok 1989 ukazał się w 2001 roku na płycie CD. Program elektroniczny powstawał we współpracy bibliografów z informatykami. Starano się zachować możliwość udostępniania bibliografii w formie elektronicznej nie tylko przez wyszukiwarki, ale też z możliwością przeglądania PBL w znanej użytkownikom formie - przez jej działy. Wymagało to konstrukcji wielu formularzy i zbudowania schematów automatycznej redakcji, z zachowaniem przepisów metodologicznych PBL, zarówno w zakresie poszczególnego zapisu bibliograficznego, jak i w obrębie całych haseł i działów ${ }^{17}$.

Początkowo zakładano, że kolejne roczniki będą miały postać CD-ROM-u, potem zadecydowano, że będą to okresy pięcioletnie. Od 2002 roku roczniki PBL udostępniane są w Internecie jako bibliograficzna baza danych o ogromnym zasięgu - rejestrująca teksty literackie zarówno polskie, jak i tłumaczone na język polski z literatur obcych, audycje radiowe, filmy fabularne, spektakle teatralne oraz opracowania na ich temat, a także bogaty materiał krytyczny i naukowy z zakresu literaturoznawstwa oraz życia literackiego. Do tej bazy włączono także materiały z rocznika 1988, który posłużył jako materiał „doświadczalny” w czasie budowy programu, oraz materiał z rocznika 1989, zawartego na płycie CD.

\footnotetext{
${ }^{16}$ T. Tyszkiewicz, op.cit., s. 28-34.

${ }^{17} \mathrm{Z}$ danych statystycznych wynika, że PBL online odwiedza rocznie ponad milion użytkowników z całego świata, którzy korzystają z bazy przez bezpośrednie wywołanie jej internetowego adresu.
} 
PBL online - bibliografia w postaci komputerowej bazy danych za lata 1989-1997 - to bibliografia nieustannie uzupełniana o nowy materiał bibliograficzny do kolejnych roczników. Ułatwia wyszukiwanie informacji bibliograficznej, daje nieograniczony dostęp do zgromadzonych informacji, a przede wszystkim umożliwia zapoznanie się z literackim dorobkiem artystycznym pisarzy polskich i obcych, osiągnięciami naukowymi literaturoznawstwa oraz wielu dziedzin związanych z literaturą. W stosunku do formy drukowanej, oferującej przeglądanie bibliografii oraz przeszukiwanie przez indeks osobowy i rzeczowy, w PBL online zachowano te możliwości, dodając nowe sposoby przeszukiwania - przez słowo w tytule (utworu, opracowania), przeglądanie wszystkich zapisów z wybranego czasopisma, wybranej literatury, z ograniczeniem czasowym do wybranych roczników oraz także przez kartotekę teatrów. Dodano opis zawartości PBL online w języku angielskim. Do pełnej wersji angielskiej z powodu trudności technicznych nie udało się dołączyć angielskiego nazewnictwa struktury działów i poddziałów. Jest to bariera w dostępie do PBL online dla użytkowników anglojęzycznych. Udostępnianie Polskiej Bibliografii Literackiej jako bazy danych wyłącznie w Internecie, bez możliwości wydruku w formie książkowej, jest również ograniczeniem dostępu, wynikającym z konieczności posiadania komputera i nieskrępowanego dostępu do Internetu ${ }^{18}$.

\section{Bibliografie drugiego obiegu}

Pierwszą bibliografią opracowaną w IBL, rejestrującą książki wydawane w obiegu niezależnym jest praca Jadwigi Czachowskiej i Beaty Dorosz Literatura i krytyka literacka poza cenzura 1977-1989 (Wrocław 1991). Bibliografia ta miała być uzupełnieniem PBL w zakresie druków zwartych, których rejestrację uniemożliwiała cenzura. Jest to pierwsza rejestracja około 1900 książek literackich wydanych w drugim obiegu, opatrzonych adnotacjami dotyczącymi ich zawartości. Oprócz utworów literackich i paraliterackich odnotowano także inne pozycje książkowe dotyczące literatury i życia literackiego, jak prace badawcze, rozmowy z pisarzami oraz dokumenty.

Swoistym świadectwem czasu, kompendium nieodzownym dla osób zajmujących się kulturą i polityką lat 80. XX wieku jest słownik opracowany przez zespół pod redakcją Dobrosławy Świerczyńskiej Kto był kim

\footnotetext{
${ }^{18}$ Zob. E. Głębicka, Jaka dokumentacja literatury jest nam dzisiaj potrzebna, w: Polonistyka w przebudowie. Literaturoznawstwo - wiedza o języku - wiedza o kulturze - edukacja. Zjazd Polonistów, Kraków, 22-25 września 2004, t. 2, Kraków 2005, s. 717-725.
} 
w drugim obiegu? Słownik pseudonimów pisarzy i dziennikarzy. 1976-1989 (Warszawa 1995).

Bibliografią literacką będącą także uzupełnieniem (o pełnym zakresie i zasięgu) Polskiej Bibliografii Literackiej, a dotyczącą okresu szczególnego we współczesnej historii Polski, jest bibliografia Jerzego Kandziory, Zyty Szymańskiej i Krystyny Tokarzówny Bez cenzury 1976-1989. Literatura, ruch wydawniczy, teatr (wyd. 1999). Bibliografia ta powstała z inicjatywy prof. Jadwigi Czachowskiej, która skierowała propozycję podjęcia prac nad bibliografią drugiego obiegu do członków Pracowni Bibliografii Bieżącej w Poznaniu w przekonaniu, że właśnie ten zespół, jako jedyny dysponuje metodą bibliograficzną potrzebną do wykonania pełnej, obejmującej także zawartość czasopism, bibliografii niezależnego ruchu wydawniczego. Doświadczenie prof. Czachowskiej w opracowywaniu unikatowych bibliografii i pomoc na każdym etapie pracy mają swój wyraz w nowatorskim układzie materiału bibliograficznego. Prof. Czachowska uświadomiła autorom, że bibliografia, rejestrując druki, dokonuje zarazem rozpoznań i interpretacji zjawisk literackich, niekiedy równych z historią literatury. Zadaniem bibliografii Bez cenzury 1976-1989 było wypełnienie luki dokumentacyjnej, jaką stanowi brak pełnej bibliografii dokonań twórczych w zakresie literatury, krytyki literackiej i teatru w Polsce, publikowanych i komentowanych w niezależnym obiegu wydawniczym w latach 1976-198919. Bibliografia rejestruje druki zwarte niezależnych oficyn wydawniczych (opracowano 3277 druków zwartych) oraz zawartość literacką, teatralną i filmową czasopism, wydawanych poza cenzurą (opracowano 226 tytułów czasopism bezdebitowych), pochodzących przede wszystkim z kolekcji prywatnych oraz zbiorów bibliotecznych. Zgromadzono 25300 opisów bibliograficznych, które usystematyzowano w działach: I. Literatura. Literatura polska (historia literatury, literatura współczesna, zagadnienia specjalne, życie literackie w latach 1976-1989), Hasła szczegółowe (antologie, śpiewniki, zbiory oraz hasła osobowe); Literatury obce (polska recepcja 52 literatur obcych); II. Ruch wydawniczy (oficjalny ruch wydawniczy, cenzura, niezależny ruch wydawniczy, ruch wydawniczy na emigracji); III. Teatr (ludzie teatru i filmu, teatr współczesny, życie teatralne w latach 1976-1989, teatry, realizacje teatralne i parateatralne); IV. Film (film polski po 1945 roku, kinematografia i polityka władz PRL wobec środowisk filmowych w latach 1976-1989, filmy). Zebrany w bibliografii materiał jest podstawą dokumentacyjną do wszelkich opracowań dotyczących polskiego niezależnego życia literacko-kulturalnego lat 1976-1989.

${ }^{19}$ J. Kandziora, Wstęp, w: J. Kandziora, Z. Szymańska, K. Tokarzówna, Bez cenzury 1976-1989. Literatura, ruch wydawniczy, teatr. Bibliografia, Warszawa 1999, s. IX-XIX. 


\section{Bibliografia literackiej zawartości czasopism XIX i XX wieku (do roku 1939)}

Bibliografia zawartości czasopism XIX i XX wieku - nazwana od nazwiska swego twórcy, Adama Bara, „Bibliografią Bara” - ma postać kartoteki, której jedna część znajduje się w Instytucie Badań Literackich w Warszawie, a druga - zawierająca materiały z czasopism wielkopolskich, pomorskich i śląskich - w Pracowni Bibliografii Bieżącej IBL PAN w Poznaniu. Dostęp do bibliografii $w$ takiej postaci jest ograniczony, a cenne informacje nie docierają do użytkowników. Podjęto zatem próby elektronicznego udostępnienia kartoteki, co też utrwaliło informację bibliograficzną zapisaną ręcznie na papierowych kartach. W tworzeniu elektronicznej wersji Bibliografii Bara wykorzystano metodę retrokonwersji.

Bibliografia Bara. Kartoteka Bibliografii Literackiej Zawartości Czasopism Polskich XIX $i$ XX wieku (do roku 1939) jest wynikiem przeniesienia opisów bibliograficznych z rękopiśmiennych kart do bazy danych. Z doświadczeń $\mathrm{w}$ tej dziedzinie wiadomo, że retrokonwersja, doprowadzająca kartotekę do postaci bazy danych, jest metodą pracochłonną i kosztowna, dającą natomiast duże możliwości wyszukiwawcze w zgromadzonym w ten sposób materiale bibliograficznym ${ }^{20}$. Obecnie materiał umieszczony w komputerowej bazie danych jest niewielki objętościowo, w całości wprowadzono jedynie hasło "Adam Mickiewicz".

Jak piszą redaktorzy Kartoteki Bara ${ }^{21}$, bibliografia ta była opracowywana w ciągu wielu lat przez zespół, którego skład się zmieniał. Spowodowało to pewne niejednolitości opracowania, czasami też niejasność (np. brak uściślającej adnotacji) lub nieczytelność zapisów. Z analizy opisów wprowadzonych do elektronicznej wersji Bibliografii Bara wynika, że informacje bibliograficzne mają znaki zapytania, a zastosowane kryterium jakości rejestrowanego materiału jest dyskusyjne (np. określenie typu opisu - nota, opracowanie, publicystyka, przeróbka itd.) i odbiega od standardów obowiązujących w bibliografiach literackich. Niedopracowane są również indeksy - indeks pism (brak wykazu opracowanych roczników i numerów), indeks teatrów (nazwy teatrów nie zawsze są w pełnej formie, występują nazwy potoczne tych instytucji) i indeks współtwórców (np. funkcje współtwórców - żołnierz i pianistka) - jest to zrozumiałe ze względu na szczątkowy materiał wprowadzony do bazy. Możliwości przeszukiwania tej bazy są jednak znacznie większe niż Polskiej Bibliogra-

\footnotetext{
${ }^{20}$ J. Sadowska, Główne problemy wspótczesnej polskiej bibliografii, w: Bibliografia. Praktyka. Dydaktyka, red. J. Woźniak-Kasperek, M. Ochmański, Warszawa 2009, s. 34-46.

${ }^{21}$ Zob. Bibliografia Bara: http://www.bar.ibl.waw.pl/.
} 
fii Literackiej (np. przeszukiwanie przez łączenie dodatkowych kryteriów, nieobecne w PBL, a świetnie funkcjonujące w Bibliografii Bara). Wydaje się, że jedyną metodą udostępnienia takich kartotek na nośnikach elektronicznych jest digitalizacja ${ }^{22}$, natomiast przygotowany program komputerowy (z pewnymi modyfikacjami) można wykorzystać do wprowadzenia drugiej części Kartoteki Bara - około 130000 kart z opisami bibliograficznymi, znajdujących się w Pracowni Bibliografii Bieżącej IBL PAN w Poznaniu, a zawierających materiały z czasopism wielkopolskich, śląskich i pomorskich. Materiał ten zebrany według metodologii PBL nie został podzielony na hasła osobowe. Znajduje się w stadium przedredakcyjnym, umożliwiającym wszelkie opracowania bibliograficzne ${ }^{23}$.

\section{Bibliografie nauki o literaturze}

Opóźnienia w rejestracji materiałów w Polskiej Bibliografii Literackiej spowodowały dotkliwy brak bieżących informacji z dziedziny literaturoznawstwa, szczególnie ważnych dla badań literackich. W odpowiedzi na potrzeby środowiska polonistycznego opracowano dwa tomy Bibliografii nauki o literaturze polskiej i teorii literatury w Polsce ${ }^{24}$ (za lata 1993 i 1994), będące fragmentem PBL ograniczonym do zagadnień, których najbardziej wartościowa informacja powinna być aktualna. W stosunku do PBL w bibliografii tej znacznie ograniczono listę źródeł i działów tematycznych. Materiały zgromadzone w działach: Ogólne (bibliografie, słowniki biograficzne); Teoria literatury; Historia literatury; Literatura współczesna; Zagadnienia specjalne (czasopiśmiennictwo, literatura dla dzieci i młodzieży, literatura ludowa, literatura regionalna, pamiętnikarstwo, polonistyka, tematy, motywy, związki literatury polskiej z literaturami obcymi); Hasła szczegółowe (utwory anonimowe i ulotne, hasła osobowe). Po wydaniu dwóch roczników inicjatywa została zarzucona.

Materiał z obu roczników tej Bibliografii o znacznie większym zakresie i zasięgu został zarejestrowany w PBL online, a podstawowa zaleta tej bibliografii - aktualność informacji bibliograficznej - zanikła. Była to jednak

${ }^{22}$ M. Pieczonka, Digitalizacja zbiorów i ich wykorzystanie w pracach badawczych bibliologa, w: Bibliologia. Problemy badawcze nauk humanistycznych, red. D.D. Kuźmina, Warszawa 2007, s. 176-194.

${ }^{23}$ Zob. Stan materiałów bibliografii retrospektywnej, w: Pracownia Bibliograficzna w Poznaniu, „Biuletyn Polonistyczny” 1958, z. 2, s. 23-24.

${ }^{24}$ J. Biesiada, A. Żurawska-Włoszczyńska, Bibliografia nauki o literaturze polskiej i teorii literatury w Polsce za rok 1993, Poznań 1995; J. Biesiada, A. Żurawska-Włoszczyńska, Bibliografia nauki o literaturze polskiej i teorii literatury w Polsce za rok 1994, Poznań 1996. 
cenna inicjatywa, potwierdzająca trwałe walory dokumentacyjne Polskiej Bibliografii Literackiej. Nadal jednak plan kontynuowania tej bibliografii jest aktualny. Ewa Głębicka postuluje wznowienie tej inicjatywy w formie bibliograficznej bazy danych, dostępnej w Internecie, która wypełniłaby lukę czasową, spowodowaną opóźnieniami PBL ${ }^{25}$. Wydaje się, że ten pomysł powinien być zrealizowany, chociażby z tego względu, że bibliografia ta stanowiłaby część PBL, którą można by było z czasem uzupełniać. Przygotowania redakcyjne do tego przedsięwzięcia (np. ustalenie listy czasopism, orientacja $\mathrm{w}$ drukach zwartych, przygotowanie struktury działów) skróciłyby czas przygotowania kolejnych roczników PBL, a materiał już zebrany do tej bibliografii nie musiałby być ponownie opracowywany.

\section{Bibliografie osobowe pisarzy}

Najczęściej monografie bibliograficzne i biobibliograficzne są pracami jednoautorskimi, przynoszącymi opracowania o pisarzu w ujęciu bardzo szerokim. Oparte są na przekonaniu, że tylko całość materiałów może stanowić podstawę do badań interpretacyjnych. Opracowania te odnotowują wszelkie przejawy twórczości, także utwory niepublikowane lub niezachowane, znane z przekazów pośrednich. Charakterystyczne cechy tych kompendiów to: ustalanie daty powstawania dzieła, próba prześledzenia jego dalszych losów; opisy bibliograficzne opatrywane adnotacjami historycznoliterackimi, dotyczącymi genezy utworów, ich powiązania z wydarzeniami z życia osobistego pisarza czy z aktualnymi wydarzeniami polityczno-społecznymi. Starano się nawet wyjaśniać aluzje zawarte w tekstach pisarza i w miarę możliwości rozszyfrowywać nazwiska bohaterów utworów, jeśli istniały ich pierwowzory. Recepcję twórczości pisarza przedstawia się w wielu wypadkach, przytaczając opinie krytyków, a także dyskusje i polemiki wywołane odbiorem utworu ${ }^{26}$.

Na szczególną uwagę zasługują nowatorskie monografie biobibliograficzne, takie jak: Julian Tuwim. Bibliografia w opracowaniu Janusza Stradeckiego (Warszawa 1959); Gabriela Zapolska. Monografia biobibliograficzna opracowana przez Jadwigę Czachowską (Kraków 1966); Tadeusz Żeleński. Twórczość i życie. Biobibliografia opracowana przez Barbarę Winklową (Warszawa 1967); Stanisław Wyspiański. Monografia bibliograficzna. T. 1-4

${ }^{25}$ Zob. E. Głębicka, op.cit., s. 720.

${ }^{26}$ Zob. B. Dorosz, Prace dokumentacyjne w badaniach literackich-dziś i jutro, w: Wiedza o literaturze i edukacja, red. T. Michałowska, Z. Goliński, Z. Jarosiński, Warszawa 1996, s. 748-749. 
w opracowaniu Marii Stokowej (Kraków 1967-1969); Twórczość Władysława Broniewskiego. Monografia bibliograficzna opracowana przez Feliksę Lichodziejewską (Warszawa 1973); Leon Kruczkowski. Monografia bibliograficzna w opracowaniu Jadwigi Kaczyńskiej (Wrocław 1992); Jarosław Iwaszkiewicz. Biobibliografia opracowana przez Beatę Dorosz (Warszawa 1994); Maria Kuncewiczowa. Monografia dokumentacyjna 1895-1989 opracowana przez Alicję Szałagan (Warszawa 1995).

\section{Bibliografie zawartości czasopism literackich}

Potrzeba udostępnienia materiałów źródłowych oraz utrwalenia dorobku czasopism wydawanych pod koniec XIX wieku i na początku XX wieku (do 1939) znalazła swoją realizację w postaci bibliografii zawartości literackiej czasopism literacko-społecznych.

W latach 1952-1955 w Instytucie Badań Literackich opracowano bibliografie zawartości roczników wybranych czasopism w dwóch seriach wydawanych pod redakcją Ewy Korzeniewskiej. Pierwsza seria - Materiały Bibliograficzne (t. 1-7, Wrocław 1953-1959) - to bibliografie pełnej zawartości wybranych czasopism XIX i XX wieku. Metoda opracowania wszystkich tomów jest jednakowa, a poszczególne tomy zawierają: wstęp (informujący o historii, programie ideowym, charakterze zawartości i danych wydawniczo-formalnych czasopisma), bibliografię zawartości w układzie alfabetycznym, krzyżowym - autorsko-przedmiotowym z włączonymi hasłami specjalnymi. Kilkanaście bibliografii z tej serii, opracowanych w formie maszynopisu lub kartoteki, do dzisiaj nie zostało opublikowanych ${ }^{27}$.

Drugą serię, zawierającą bibliografię oraz antologię tekstów wybranych czasopism literacko-społecznych XIX i XX wieku, nazwano Materiały do Dziejów Postępowej Publicystyki (t. 1-4, Wrocław 1952-1955). Z relacji Czachowskiej dowiadujemy się, że pierwotnie każdy tom miał zawierać szkic omawiający dzieje periodyku, antologię wybranych tekstów oraz pełną bibliografię. Jedną z pierwszych prac $\mathrm{w}$ tej serii była bibliografia Czachowskiej Sygnały 1933-1939. Bibliografia zawartości (wyd. 1952). Jednak z powodu ingerencji cenzury, wartość tych bibliografii została znacznie zubożona ${ }^{28}$. O swojej bibliografii Sygnały 1933-1939. Bibliografia zawartości ${ }^{29}$ autorka pisze:

${ }^{27}$ Zob. ibidem, s. 751-752.

${ }^{28}$ J. Czachowska, Zmagania z cenzura słowników i bibliografii literackich w PRL, w: Piśmiennictwo, systemy kontroli, obiegi alternatywne, t. 2, Warszawa 1992, s. 225-226.

${ }^{29}$ J. Czachowska, Sygnały 1933-1939. Bibliografia zawartości, Wrocław 1952 (Materiały do Dziejów Postępowej Publicystyki. Instytut Badań Literackich Polskiej Akademii Nauk, 2). 
Pierwszy tom (przygotowany przeze mnie) poświęcony był „Sygnałom”, pismu społeczno-literackiemu demokratycznej i postępowej inteligencji, wydawanemu we Lwowie w latach 1933-1939. Przed odesłaniem maszynopisu do Ossolineum ocenzurował go ówczesny sekretarz naukowy IBL, Samuel Sandler, który m.in. zredukował bibliografię pełnej zawartości do „wykazu ważniejszych pozycji bibliograficznych”, przy czym określenie „ważniejszych" odpowiadało jedynie ocenie z punktu widzenia ideowopolitycznego i ówczesnych zaleceń cenzury. Skreślono więc hasła autorsko-przedmiotowe dotyczące wielu pisarzy współpracujących z czasopismem lub będących przedmiotem artykułów i recenzji zamieszczanych na jego łamach, m.in. Czuchnowskiego, Wacława Iwaniuka, Marii Kuncewiczowej, Stanisława J. Leca, Miłosza, Herminii Nagierowej, Sergiusza Piaseckiego, Elżbiety Szemplińskiej-Sobolewskiej, Terleckiego. Zasada eliminacji była prosta: zapisem objęto pisarzy, którzy w tym czasie przebywali na emigracji. Usunięto też całkowicie hasło „Stanisław Brzozowski”: jego artykuł „Marksizm i filozofia", listy pisarza, a także 5 ważkich artykułów poświęconych Brzozowskiemu, którego filozofia odgrywała istotną rolę w światopoglądzie grupy skupionej wokół „Sygnałów”. Wyeliminowano również hasła poświęcone literaturom obcym: Louisowi F. Celine'owi, Andre Gide'owi, Ernstowi Glaeserowi, Aldousowi Huxleyowi, Andre Malraux, Heinrichowi Mannowi, Jean Moulin'owi i innym. Ogółem usunięto ok. 40\% wszystkich opisów bibliograficznych, co w istotny sposób sfałszowało obraz zawartości pisma i jego oblicza ideologicznego. Propozycję, aby wprowadzić przynajmniej tytuł „Wybór pozycji bibliograficznych”, rezygnując z określenia „ważniejszych”, odrzucono ${ }^{30}$.

\section{Bibliografie gatunków, motywów literackich}

Bibliografie gatunków literackich są szczególnie przydatne i potrzebne do badań nad literaturą staropolską. Pierwszą pracą dokumentacyjną z szeregu monografii bibliograficznych piśmiennictwa staropolskiego była Bibliografia powieści polskiej 1601-1800 w opracowaniu Jadwigi Rudnickiej (Wrocław 1964). Zarejestrowane utwory (834 druki zwarte i niesamoistne wydawniczo oraz prace w rękopisie) to dzieła pisane przez autorów polskich w języku polskim oraz wszystkie inne utwory, które były drukowane na ziemiach Rzeczypospolitej w XVII i XVIII wieku bez względu na język lub tematykę. Każdy opis utworu ma adnotację dotyczącą literatury przedmiotu oraz inne uwagi szczegółowe.

${ }^{30}$ J. Czachowska, Zmagania z cenzura..., s. 225-226. 
Prace nad bibliografią dramatu staropolskiego, zatytułowane Dramat staropolski od początków do powstania Sceny Narodowej pod redakcją Alodii Kaweckiej-Gryczowej, zaowocowały opublikowaniem dwóch tomów: t. 1: Teksty dramatyczne drukiem wydane do 1765 pod redakcją Władysława Korotaja (Wrocław 1965) rejestruje widowiska liturgiczne, misteria, dialogi religijne, moralitety, dramaty antyczne, komedie rybałtowskie, dramaty szkolne, teatr dworski oraz teatry prywatne (odnotowano wszystkie te utwory, które zawierają element teatralny), a szczegółowy opis poszczególnych haseł połączono $\mathrm{z}$ informacjami na temat bibliografii przedmiotowej; t. 2, cz. 1: Programy teatru jezuickiego (Wrocław 1976) i cz. 2: Programy teatru pijarskiego oraz innych zakonów i szkół katolickich (Wrocław 1978). Bibliografia ta zaopatrzona jest w dużą liczbę indeksów, co znakomicie ułatwia poruszanie się po niej i może być wzorem dla opracowania innych bibliografii tego typu. Kolejny tom - Szkoły różnowiercze. Teatr królewski $\mathrm{w}$ postaci maszynopisu od kilku lat czeka na wydanie ${ }^{31}$.

Nie opracowano natomiast dotąd naukowej bibliografii tematów i motywów literackich ${ }^{32}$. Vrtel-Wierczyński zakładał zbieranie materiałów do takiej bibliografii na etapie zbierania materiałów do PBL ${ }^{33}$. Inicjatywa ta jednak została odrzucona ${ }^{34}$. Przygotowanie rozprawy doktorskiej Vrtela--Wierczyńskiego Przyroda w warszawskim okresie twórczości Zygmunta Krasińskiego (Lwów 1912) spowodowało zapewne dobre rozeznanie tematyki motywów w utworach literackich i stwierdzenie braku odpowiednich opracowań bibliograficznych w tej dziedzinie ${ }^{35}$.

${ }^{31}$ Zob. E. Głębicka, op.cit., s. 723.

${ }^{32}$ Zob. B. Dorosz, Prace dokumentacyjne..., s. 741-755.

${ }^{33}$ W roczniku PBL za rok 1948 (wyd. 1954), w "Skorowidzu przedmiotowym” (s. 553-568), zindeksowane zostały m.in. teksty literackie uszeregowane według motywów literackich. Wyszczególniono 15 motywów obecnych w utworach literackich roku 1948. Są to: Boże Narodzenie (56 utworów); Don Kichot (4 utwory); Górnictwo (25 utworów); Góry w literaturze (45 utworów); Hamlet (5 utworów); Janosik i zbójnictwo (9 utworów); Legendy i podania (32 utwory); Lotnictwo (27 utworów); Morze i marynistyka (106 utworów); Odbudowa i budownictwo socjalistyczne (7 utworów); Pierwszy maj (20 utworów); Polska i Polacy w literaturze zagranicznej (33 utwory); Sport (35 utworów); Warszawa (140 utworów); Wojna (241 utworów). Koncepcja Wierczyńskiego dotycząca indeksowania przedmiotowego nie tylko opracowań, ale też tekstów literackich pod kątem gatunków, tematów i motywów została odrzucona w 1956 roku. Zob. J. Czachowska, Rozwój bibliografii..., s. 135, 139.

${ }^{34}$ S. Vrtel-Wierczyński jest autorem Polskiej bibliografii o morzu, dołączonej do książki Kronika o polskiem morzu. Dzieje walk, zwycięstw i pracy, red. C. Peche, Warszawa 1930.

${ }^{35}$ Zob. T.S. Grabowski, Śp. Stefan Vrtel-Wierczyński. Jego działalność naukowa i bibliograficzna, „Slavia Occidentalis" 23, 1963, s. V-X. 


\section{Bibliografie bibliografii, przewodniki dla użytkowników bibliografii literackich}

Zasadniczym kompendium dla warsztatu badawczego polonisty, a zarazem informatorem o podstawowych bibliografiach i leksykonach (bibliografia bibliografii) oraz o miejscach udostępniania bazy źródłowej jest praca Jadwigi Czachowskiej i Romana Lotha Przewodnik polonisty. Bibliografie. Słowniki. Biblioteki. Muzea literackie (Wrocław 1974 oraz aktualizowane wydania w 1981 i 1989).

Przewodnik polonisty, jak czytamy w Przedmowie, jest usystematyzowanym spisem bibliografii i informatorów rejestrujących teksty literackie, prace badawcze o różnych zasięgach przedmiotowych i chronologicznych, którego zadaniem jest sprawne posługiwanie się całym zasobem tych opracowań. Opracowaniami są tutaj zarówno druki zwarte, jak też publikacje czasopiśmiennicze. W intencji autorów miał to być punkt wyjścia dla poszukiwań wszelkiej informacji źródłowej z dziedziny literatury i nauki o literaturze. W części pierwszej Bibliografie, słowniki oraz inne opracowania dokumentacyjne (oprac. Czachowska), w sześciu działach podane są opisy bibliograficzne odpowiednich kompendiów (także bibliografii literackich opracowanych w IBL) oraz ich krótka charakterystyka wraz z adresami bibliograficznymi ich recenzji i omówień. Część druga, zatytułowana Biblioteki i muzea literackie (oprac. Loth), w trzech działach informuje o zasobach bibliotecznych i muzealnych, zawierających źródła, do których odsyła bibliografia. Ostatnie, trzecie wydanie Przewodnika polonisty (1989) ukazuje stan bibliografii z 31 grudnia 1985 roku.

Przewodnik polonisty wskazuje na ścisłe powiązanie bibliografii literackiej z bibliotekami i zasobami bibliotecznymi, a brak uzupełnionego, zaktualizowanego wydania uniemożliwia orientację $\mathrm{w}$ aktualnym dorobku $\mathrm{w}$ tej dziedzinie.

\section{Cenzura w bibliografiach literackich}

Opracowane bibliografie drugiego obiegu wydawniczego wskazują na ogromną liczbę publikacji, które nie mogły ukazać się w obiegu oficjalnym ze względu na system kontroli państwowej obowiązujący wszystkie publikacje $^{36}$. Nadzorowi i ingerencji Głównego Urzędu Kontroli Prasy, Publikacji i Widowisk podlegało również rozpowszechnianie wszelkiego rodzaju druków, zapisów obrazu i słowa, każde publiczne wykonanie

\footnotetext{
${ }^{36}$ Problematykę związaną z cenzurą totalną w PRL przedstawia w swojej książce Jadwiga Kołodziejska, Za drzwiami bibliotek, Warszawa 1996, s. 81-96.
} 
utworu z tekstem słownym albo utworu mimicznego w działalności artystycznej lub rozrywkowej ${ }^{37}$.

Niewiele wiadomo o ingerencjach cenzury w teksty naukowe, a szczególnie mało jest danych o kontroli cenzorskiej w opracowaniach informacyjnych i dokumentacyjnych, które były nią objęte w latach 1946-1989. Cenzura prewencyjna miała zapobiegać godzeniu w ustrój państwa polskiego, ujawnianiu tajemnic państwowych, naruszaniu międzynarodowych stosunków państwa polskiego, naruszaniu prawa lub dobrych obyczajów, wprowadzaniu w błąd opinii publicznej przez podawanie wiadomości niezgodnych z rzeczywistością.

Przeglądając pierwsze powojenne bibliografie literackie, użytkownik może dostrzec zdeformowane opisy bibliograficzne, nazewnictwo odbiegające od przyjętych zasad, braki w pozycjach numerowanych bibliografii, jak też numery łamane. Należy zatem wspomnieć o zabiegach, jakim bibliografie były poddawane $\mathrm{w}$ okresie między oddaniem maszynopisu do wydawnictwa a ich wydrukowaniem. Dowody na ingerencje cenzury $\mathrm{w}$ kompendia bibliograficzne to przede wszystkim strony $\mathrm{z}$ maszynopisów z zaznaczonymi skreśleniami, nieliczne pisma urzędowe i korespondencja osób zaangażowanych w sprawy wydawnictw bibliograficznych, a przede wszystkim relacje świadków - autorów i redaktorów. Celem tych zabiegów, jak pisze Czachowska, było kształtowanie określonego obrazu przeszłości przez dobór materiału i odpowiednich informacji ${ }^{38}$. Wielu z przygotowanych już do wydania bibliografii cenzura nie dopuściła do druku, inne pozostały w postaci kartotek.

Z omówionych wyżej bibliografii szczególnym zabiegom cenzorskim podlegały: Polska Bibliografia Literacka, Słownik współczesnych pisarzy polskich, serie bibliografii zawartości czasopism, m.in. Materiaty do Dziejów Postępowej Publicystyki. Z korpusu bibliografii wykreślano nazwiska pisarzy, najczęściej tworzących na emigracji, skreślano niewygodne tytuły utworów i opracowań, usuwano partie materiałów z kompletnej bibliografii zawartości czasopism, czyniąc z niej bibliografię selektywną, a tym samym nieprzydatną do dalszych badań naukowych. Dzisiaj dysponujemy nielicznymi wprawdzie, ale źródłowymi informacjami na ten temat. Działania cenzury przedstawimy na przykładach zaczerpniętych z Polskiej Bibliografii Literackiej, a dotyczą one najwcześniej wydanych roczników.

${ }^{37}$ Zob. B. Dorosz, Literatura i krytyka literacka w drugim obiegu (1977-1989). Rekonesans bibliograficzny w zakresie druków zwartych, w: Piśmiennictwo - systemy kontroli-obiegi alternatywne, red. J. Kostecki, A. Brodzka, t. 2, Warszawa 1992, s. 335-355.

${ }^{38}$ J. Czachowska, Zmagania z cenzura..., s. 214-235. 
Pierwszy tom PBL za rok 1948, złożony do druku w 1950 roku, został opublikowany w roku 1954. Wprowadzona w życie koncepcja bibliografii literackiej Vrtela-Wierczyńskiego - polegająca na rejestracji bibliograficznej materiału bieżącego (druki zwarte i materiał z czasopism), przeprowadzonej według określonych przepisów metodologicznych - została poddana szczególnym zabiegom cenzorskim, a także cenzurze wewnętrznej IBL (w latach 1948-1956), który był podmiotem odpowiedzialnym za przygotowywanie takiej pracy. Opis tych zabiegów przytoczymy za relacją Krystyny Tokarzówny, współredaktorki tego tomu, późniejszej kierowniczki Pracowni Bibliografii Bieżącej IBL PAN w Poznaniu ${ }^{39}$.

Jak czytamy w artykule Cenzura w "Polskiej Bibliografii Literackiej", pierwszą sprawą, którą zakwestionowała Dyrekcja IBL, był układ literatur obcych - sporządzony alfabetycznie według literatur narodowych, wskutek czego „Literatury narodów ZSRR” znalazły się na samym końcu. Okazało się, że taki układ działał „na szkodę międzynarodowych stosunków państwa polskiego" według artykułu 2. dekretu o cenzurze z 5 lipca 1946 roku. Po burzliwych dyskusjach przyjęto układ, który obowiązywał w rocznikach PBL za lata 1944/1945-1949: na początek działu wysunięto „Literatury narodów ZSRR”, następnie wszystkie inne literatury ułożono alfabetycznie, stosując odsyłacze do literatur poszczególnych republik radzieckich. Redaktor naukowy tomów PBL za lata 1947 i 1948 (Barbara Rafałowska) zażądała między innymi usunięcia z gotowej już bibliografii źródeł czasopiśmienniczych (głównie pism religijnych), kilku źródeł angielskich i amerykańskich, skreślenia opisu wydanych w kraju utworów pisarzy polskich przebywających na emigracji, usunięcia utworów pisarzy jugosłowiańskich. Ostatecznie usunięto 24 źródła czasopiśmiennicze, skreślono napiętnowane hasła osobowe (nie pojawiały się one w rocznikach za lata 1944/1945, 1946, 1947, 1949, drukowanych w latach 1956-1958).

Cenzura wrocławska ${ }^{40}$ natomiast domagała się transkrypcji fonetycznej nazwisk pisarzy ZSRR, transliterowanych z grażdanki, zgodnie z zasadami katalogowymi. W rezultacie wprowadzono pisownię nazwisk $\mathrm{w}$ transliteracji i w grażdance. Ten system utrzymano $\mathrm{w}$ rocznikach PBL za lata 1944/1945-1949 i 1956-1959, potem go zaniechano. Zakwestionowano również informacje o 40 pisarzach, którzy 24 sierpnia 1947 roku pod-

\footnotetext{
${ }^{39}$ K. Tokarzówna, Cenzura w „Polskiej Bibliografii Literackiej”, w: Piśmiennictwo - systemy kontroli - obiegi alternatywne, red. J. Kostecki, A. Brodzka, t. 2, Warszawa 1992, s. $237-250$.

${ }^{40}$ Zakład Narodowy im. Ossolińskich we Wrocławiu podlegał terenowemu Urzędowi Głównego Urzędu Kontroli Prasy, Publikacji i Widowisk we Wrocławiu.
} 
pisali Uchwałę Związku Pisarzy Polskich na Obczyźnie, stwierdzająca, że umieszczanie utworów dawnych i nowych w prasie krajowej „byłoby nie tylko niegodne pisarza polskiego, wiernego prawdzie i wolności myśli, lecz także złowrogie dla kształtowania się twórczości polskiej w tym okresie" ${ }^{41}$.

W momencie zmian politycznych w 1956 roku, jak relacjonuje Tokarzówna, zespół PBL przygotował do publikacji te wszystkie dane, które z przyczyn cenzuralnych lub niedostępności w bibliotekach nie znalazły się w opublikowanych tomach. Z tego też powodu w tomie PBL za 1949 rok (wydanym w 1958) znalazł się Dodatek za lata 1944-1949, obejmujący ponad 1400 pozycji. Były to utwory z usuniętych przez cenzurę czasopism polskich i druki zwarte będące polonikami zagranicznymi. Jak stwierdza dalej Tokarzówna, wszystkim użytkownikom PBL za lata 1944-1949 należy uświadomić, że tomy te, choć wzbogacone o Dodatek, nie obejmują materiałów z czasopism emigracyjnych. W podsumowaniu artykułu Tokarzówny czytamy, że Polska Bibliografia Literacka podlegała kontroli cenzury do rocznika 1983 (wyd. 1990-1991), a rocznik 1984 (wyd. 1993), redagowany jeszcze pod presją cenzury, nie objął publikacji drugiego obiegu. W roczniku 1985 (wyd. 1993) PBL zarejestrowała druki zwarte wydawane w obiegu niezależnym, a rocznik 1986 (wyd. 1995) zawiera całą produkcję wydawnicza, razem z periodykami krajowymi, ich reedycjami i dostępnym w kraju dorobkiem emigracji ${ }^{42}$.

Możemy dodać, że w latach 1995-1998 opracowano kompletną bibliografię drugiego obiegu Bez cenzury 1976-1989 (wyd. 1999), wskutek czego nie dublowano już tych materiałów w PBL za lata 1987-1989. Zawartość roczników PBL za lata 1976-1989 można zestawiać i porównywać z zawartością bibliografii Bez cenzury 1976-1989, gdyż obie bibliografie opracowane zostały według tej samej metodologii bibliograficznej.

${ }^{41}$ Cyt. za: K. Tokarzówna, Cenzura w „Polskiej Bibliografii Literackiej”, s. 240; uchwałę podpisali: Ignacy Baliński, Stanisław Baliński, Antoni Bogusławski, Wiktor Budzyński, Józef Bujnowski, Wawrzyniec Czereśniewski, Marian Czuchnowski, Maria Danilewiczowa, Stefan Gacki, Mieczysław Giergielewicz, Ferdynand Goetel, Wacław Grubiński, Marian Hemar, Józef Kisielewski, Julian Krycki, Marian Kukiel, Stanisława Kuszelewska-Rajska, Jan Lechoń, Mieczysław Lisiewicz, Herminia Naglerowa, Jerzy Niezbrzycki [Ryszard Wraga], Zygmunt Nowakowski, Beata Obertyńska, Jan Olechowski, Hanna Peretiatkowicz, Sergiusz Piasecki, Halina Pilichowska, Aleksander Piskor, Andrzej Pomian-Dowmuntt, Adam Pragier, Nikodem Sądek, Stanisław Stroński, Władysław Studnicki, Tadeusz Sułkowski, Stefania Szurlej-Kossowska, Tymon Terlecki, Wiktor Weintraub, Kazimierz Wierzyński, Stefania Zahorska, Józef Żywina.

${ }^{42}$ Ibidem, s. 250. 


\section{Stan obecny i perspektywy rozwoju bibliografii literackich}

Ogromny dorobek Instytutu Badań Literackich w zakresie bibliografii literackich został ograniczony $w$ tym artykule do przeglądu najważniejszych pozycji. Starałam się ukazać różnorodność bibliografii, ich zawartość, a także problematykę związaną z cenzurą bibliografii. W latach 80 . XX wieku nastąpił znaczny regres $\mathrm{w}$ dziedzinie bibliografii literackich, opracowywanych w IBL PAN. Diagnozę tego stanu rzeczy - aktualną i dziś - w 1996 roku próbowała sformułować Beata Dorosz:

W środowisku bibliografów-dokumentalistów istnieje głębokie przekonanie, że $\mathrm{w}$ latach osiemdziesiątych nastąpił zdecydowany regres, tak w kontynuowaniu i aktualizowaniu przedsięwzięć podstawowych, jak i podejmowaniu nowych poczynań w węższym zakresie. Wobec braku dostatecznych środków finansowych na naukę i konieczność dokonywania wyboru, gdy chodzi o dotowanie prac, część badaczy uważała, iż należy ograniczyć prace bibliograficzne na rzecz prac interpretacyjnych, zwłaszcza reprezentujących nowe kierunki badawcze. Stanowisko to uznać należy za daleko posuniętą nonszalancję, gdyż informacja i dokumentacja stanowią warunek właściwego rozwoju nauki o literaturze i powinny być równorzędnym partnerem dla prac interpretacyjnych. Nastąpiło dramatyczne zmniejszenie zespołów realizujących wielkie przedsięwzięcia bibliograficzne, na miejsce osób odchodzących na emeryturę nie przyjmowano dostatecznie wcześnie nowych pracowników, co pozwoliłoby we właściwy sposób przygotować kadrę młodych polonistów-dokumentalistów. Trudności wydawnicze spowodowały opóźnianie się publikacji kompendiów i starzenie się informacji1 ${ }^{43}$.

Patrząc na recepcję bibliografii literackich w środowisku akademickim i naukowym, dostęp do nich i funkcjonowanie w obiegu informacji naukowej, dochodzi się do wniosku, że te wszystkie osiągnięcia w zakresie bibliografii literackich nie zostały odpowiednio wykorzystane, a publikacje o znacznie mniejszej wartości naukowej i opracowane przez specjalistów niższej rangi zajmują poczesne miejsce $\mathrm{w}$ dydaktyce literatury i informacji naukowej. Można by się pokusić o stwierdzenie, że to właściwie cenzura najbardziej doceniała bibliografie literackie, potrafiąc wyłuskać z nich najcenniejsze informacje i ukryć je przed użytkownikami. Niskonakładowe publikacje, udostępniane tylko badaczom literatury, wiele cennych bibliografii w postaci kartotek, nieumiejętność korzystania z bibliografii literackich przez ich użytkowników, najczęściej spowodowane brakiem dydakty-

${ }^{43}$ B. Dorosz, Prace dokumentacyjne..., s. 752. 
ki w tym zakresie - spychają te wielkie i opracowane z dużym wysiłkiem dzieła na mało dostępne półki biblioteczne, czy też do archiwów.

Wiele prac dokumentacyjnych zainicjowanych w minionych latach nie zostało ukończonych, inne przerwano, część opracowań pozostała w maszynopisie lub kartotece ${ }^{44}$.

W opracowaniach bibliograficznych są też duże luki dokumentacyjne. Do tej pory nie powstało odpowiednie kompendium naukowe ukazujące całościowo recepcję literatur obcych w Polsce i geografię przekładów utworów obcojęzycznych. Pisała o tym Głębicka:

Wobec nowych zadań, jakie stoją przed badaniami literackimi w związku z nową pozycją Polski w Europie, zaplecza dokumentacyjnego będą wymagały wkrótce ogromne obszary związków literatury polskiej z literaturami innych krajów, obecność obcych literatur w Polsce; dotyczy to także przenikania wpływów na poziomie nauki o literaturze. Zadanie to może być odpowiedzialnie wykonane jedynie w sytuacji, gdy dostępne będą poświęcone mu opracowania dokumentacyjne oraz rozwinięta sieć baz danych ${ }^{45}$.

Nie opracowano również odpowiedniego wykazu braków w przekładach na język polski arcydzieł literatury światowej z różnych epok. Materiały do opracowań tego typu są zawarte w rocznikach PBL, w dziale „Literatury obce”, który obejmuje polską recepcję około 160 literatur narodowych w latach 1944-1997.

Ostatnia z bibliografii opracowywanych cyklicznie w Instytucie Badań Literackich - Polska Bibliografia Literacka w postaci komputerowej bazy danych PBL online - pokazuje, że bibliografia literacka może być użyteczna dla różnych kategorii użytkowników, nie tylko polonistów i badaczy literatury. Ogólnodostępna w Internecie baza bibliograficzna, jak wynika z analizy programu statystycznego, ma tysiące użytkowników w każdym miesiącu. Ożywiona korespondencja elektroniczna zespołu autorskiego PBL z autorami i badaczami literatury polskiej na całym świecie (pojęcie emigracji straciło tutaj swoje znaczenie) przynosi dużo nowych informacji i pozwala korygować błędy w bibliografii oraz uzupełniać braki. Bibliotekarze penetrują tę bazę w poszukiwaniu druków zwartych, których nie rejestruje "Przewodnik Bibliograficzny", liczni autorzy szukają recenzji swoich książek, obcy pisarze są zainteresowani polską recepcją swojej twórczości, studenci i maturzyści przeszukują bazę podczas pisania swoich prac itd. Niestety, wiele wskazuje na to, że z powodu wielu trudności,

\footnotetext{
${ }^{44} \mathrm{O}$ tych pracach wspomina Ewa Głębicka, op.cit., s. 723-724.

${ }^{45}$ Ibidem, s. 725.
} 
niezależnych od opracowującego ją zespołu, i ta bibliografia podzieli los wielkich bibliografii retrospektywnych i nie stanie się już nigdy bibliografią bieżącą. Złudne są nadzieje, że komputeryzacja i komputerowe bazy danych rozwiążą ten problem. Beata Dorosz przestrzega przed zachwytem nad komputeryzacją bibliografii:

Istnieje bowiem wśród osób nie znających specyfiki prac bibliograficzno-dokumentacyjnych tyleż szeroko rozpowszechniane, co z gruntu błędne przekonanie, że wykorzystanie komputera może zlikwidować wszelkie problemy związane $\mathrm{z}$ tego typu działalnością naukową. Tymczasem wieloletnie doświadczenia bibliografów praktyków dowodza, że komputer może być tylko narzędziem pomocnym, lub usprawniającym pracę. Warunkiem absolutnie podstawowym i koniecznym dla dalszego rozwoju bibliografii jest jednak przede wszystkim potrzeba odtworzenia kadry wysoko wyspecjalizowanych polonistów-dokumentalistów, świadomych wagi wykonywanych przez siebie prac dla całej nauki o literaturze ${ }^{46}$.

Opracowanie naukowej bibliografii literackiej, jaką jest Polska Bibliografia Literacka, nie jest przedsięwzięciem adresowanym do jednego pokolenia, o czym można się przekonać, patrząc na liczbę roczników opracowanej bibliografii. Jako bibliografia prymarna, PBL jest źródłem do opracowywania innych, bardziej szczegółowych bibliografii. Każde ograniczenie zasięgu tej bibliografii, mające przyspieszyć jej opracowanie i uczynić bardziej aktualną budzi protesty środowiska naukowego. W przeszłości próbowano już zrezygnować z działu „Teatr”, co wywołało protesty środowiska naukowego i odstąpiono od tego zamiaru ${ }^{47}$. W artykule Głębickiej Jaka dokumentacja literatury jest nam potrzebna czytamy:

Od początku wyodrębnienia dokumentacji literatury jako dyscypliny badawczej, wykonawcą opracowań dokumentacyjnych byli poloniści, specjalizujący się w pracach bibliograficznych i faktograficznych, a ich wysiłek wynikał z przekonania, że podstawą rzetelnych badań historycznoliterackich i wszelkiej konstrukcji i nadbudowy interpretacyjnej jest stworzenie bazy faktograficznej [...]. Jeśli chodzi o bibliografię bieżącą - trudności zaczynają się i mnożą już na podstawowym dla tej dziedziny poziomie rejestrowania wydawanych utworów literackich, a czasem też opracowań badawczych. Od kilku lat sytuacja jest stabilna i sprowadza się do budzącego grozę faktu, iż blisko 40\%

\footnotetext{
${ }^{46}$ B. Dorosz, Prace dokumentacyjne ..., s. 755.

${ }^{47}$ Zob. J. Degler, Nauka w niebezpieczeństwie! (O projekcie zmian w Polskiej Bibliografii Literackiej), „Teatr” 1998, nr 1, s. 56-58.
} 
wydawanych w Polsce książek nie wpływa do Biblioteki Narodowej i nikt nie jest w stanie wyegzekwować tzw. egzemplarza obowiązkowego; pozycje te nie są więc odnotowywane w „Przewodniku Bibliograficznym”, a więc formalnie rzecz ujmując - nie istnieją. [...] Skoro tak utrudnione staje się dotarcie do publikacji książkowych, można sobie wyobrazić kłopoty, związane z dokumentacją życia literackiego. Wiąże się to także z wymuszoną przez sytuację finansową i etatową reorganizacją zakresu gromadzenia materiału w Polskiej Bibliografii Literackiej, w której znacząco ograniczono listę opracowanych czasopism, rezygnując z dzienników lokalnych i pism regionalnych. Dodatkowo - opóźnienia w wydawaniu tego bezcennego źródła informacji bibliograficznej spowodowały, że nie dysponujemy i szybko mieć nie będziemy bieżącej bibliografii literackiej ${ }^{48}$.

Ostatnie zmiany struktury działu „Teoria literatury” w PBL online zostały dokonane na podstawie najnowszych badań w tej dziedzinie, co jest zaletą dla użytkownika bibliografii (materiał bibliograficzny dotyczący określonego zagadnienia zgromadzony jest w jednym miejscu), natomiast zespół opracowujący bibliografię musi rozszerzyć pole penetracji bibliograficznej o nowe zagadnienia.

Od bibliografii literackich oczekuje się pełnej, nieselektywnej i rzetelnej informacji także po zmianie nośnika informacji ${ }^{49}$. Ład bibliograficzny i związany $\mathrm{z}$ nim ład informacyjny są konieczne $\mathrm{w}$ warunkach przyrostu wiedzy przedmiotowej i, na co się liczy, przyrostu bieżącej informacji bibliograficznej. Oczekuje się, że opracowanie kolejnych roczników PBL wpłynie również korygująco na ustalenia interpretacyjne powstałe - z powodu opóźnienia dokumentacji bibliograficznej - bez oparcia na tym naukowym źródle.

\footnotetext{
${ }^{48}$ E. Głębicka, op.cit., s. 717-719.

${ }^{49}$ Zob. A. Borysowska, Bibliologia a literaturoznawstwo - pokrewieństwo warsztatów historyka książi i historyka literatury, w: Bibliologia. Problemy badawcze nauk humanistycznych, Warszawa 2007, s. 85-98.
} 


\title{
The literary bibliography in the Institute of Literary Research - IBL PAN (1948-2010): Origin, achievements and future
}

\begin{abstract}
Aвstract. The article discusses literary bibliographies prepared in the Institute of Literary Research of the Polish Academy of Sciences (IBL PAN), their origin, specificity and the assumptions adopted for the preparation of various and diversified types of bibliographies. A particular attention is given to literary bibliographies with a wide scope and range of the sources included that are usually the result of a team work such as: Bibliografia literatury polskiej "Nowy Korbut" and the dictionaries Stownik pisarzy polskich (Series I and II) and Wspótcześni polscy pisarze i badacze literatury; Dawni pisarze polscy. Od początków piśmiennictwa do Młodej Polski. Przewodnik biograficzny i bibliograficzny; Słownik pseudonimów pisarzy polskich (XV w.-1995), Literatura polska i teatr w latach II wojny światowej. Bibliografia; Polska Bibliografia Literacka; Literatura i krytyka literacka poza cenzura 1977-1989; Kto byt kim w drugim obiegu? Słownik pseudonimów pisarzy i dziennikarzy. 1976-1989; Bez cenzury 1976-1989. Literatura, ruch wydawniczy, teatr. Bibliografia; Bibliografia Bara. Kartoteka Bibliografii Literackiej Zawartości Czasopism Polskich XIX i XX wieku (do roku 1939). These bibliographies aim at presenting the facts from the literary and cultural life of Poland from the earliest times of writing to modern times. Two electronic versions of the literary bibliography - PBL on-line - are presented as a continuation of the printed book Polska Bibliografia Literacka, and Bibliografia Baraelectronic version of the bibliographical file catalogue Bibliografia Bara. Kartoteka Bibliografii Literackiej Zawartości Czasopism Polskich XIX i XX wieku (do roku 1939) worked out and edited by Adam Bar, initiated during the second world war and completed in the 1950s. Additionally, the author discusses the problem of censorship of literary bibliographies in the years 1948-1989, current situation in methods for compiling literary bibliographies and provides a short outline of the problems in documentation of areas not yet covered by bibliographical records.

All the presented bibliographies are retrospective bibliographies. Hence, a necessity has arisen as to work out a far-reaching plan to be prepared for the PBL, i.e. a current bibliography that is a fundamental compendium of information on literature and the theory of literature, a form of a basic workshop for literary studies and a source for many other bibliographical works, as well as a fundamental tool for literary criticism.
\end{abstract}

Key words: bibliography, literary bibliography, Polish Literary Bibliography (PBL), literature, history of literature, literary motifs, film, television, research information, research documentation, Institute of Literary Research, censorship. 
